\title{
Front Matter: Volume 7152
}

, "Front Matter: Volume 7152," Proc. SPIE 7152, Remote Sensing of the Atmosphere and Clouds II, 715201 (13 January 2009); doi:

10.1117/12.821949 


\title{
PROCEEDINGS OF SPIE
}

\section{Remote Sensing of the Atmosphere and Clouds II}

\author{
Graeme L. Stephens \\ Takashi Y. Nakajima \\ Editors
}

\author{
18 November 2008 \\ Noumea, New Caledonia
}

\begin{abstract}
Cosponsored by
Gouvernement de la Nouvelle-Calédonie (New Caledonia) • IRD—Institut de Recherche pour le Développement (France) - SPC - Secretariat of the Pacific Community •ISRO-Indian Space Research Organization (India) • NASA-National Aeronautics and Space Administration (United States) • Scripps Institution of Oceanography, University of California, San Diego (United States) - Secretariat Permanent pour le Pacifique, République Française (France) - JAXA—Japan Aerospace Exploration Agency (Japan) • NiCT-National Institute of Information and Communications Technology (Japan) NOAA-National Oceanic and Atmospheric Administration (United States)

Cooperating Organizations

CCG-International Ocean Colour Coordinating Group • IFREMER-Institut Français de Recherche pour l'Exploitation de la Mer (France) • Université de la Nouvelle-Calédonie (New Caledonia)

SOPAC-Pacific Islands Applied Geoscience Commission

Published by

SPIE
\end{abstract}

Volume 7152 
The papers included in this volume were part of the technical conference cited on the cover and title page. Papers were selected and subject to review by the editors and conference program committee. Some conference presentations may not be available for publication. The papers published in these proceedings reflect the work and thoughts of the authors and are published herein as submitted. The publisher is not responsible for the validity of the information or for any outcomes resulting from reliance thereon.

Please use the following format to cite material from this book:

Author(s), "Title of Paper," in Remote Sensing of the Atmosphere and Clouds II, edited by Graeme L. Stephens, Takashi Y. Nakajima, Proceedings of SPIE Vol. 7152 (SPIE, Bellingham, WA, 2008) Article CID Number.

ISSN 0277-786X

ISBN 9780819473943

Published by

SPIE

P.O. Box 10, Bellingham, Washington 98227-0010 USA

Telephone +1 3606763290 (Pacific Time) · Fax +1 3606471445

SPIE.org

Copyright (@ 2008, Society of Photo-Optical Instrumentation Engineers

Copying of material in this book for internal or personal use, or for the internal or personal use of specific clients, beyond the fair use provisions granted by the U.S. Copyright Law is authorized by SPIE subject to payment of copying fees. The Transactional Reporting Service base fee for this volume is $\$ 18.00$ per article (or portion thereof), which should be paid directly to the Copyright Clearance Center (CCC), 222 Rosewood Drive, Danvers, MA 01923. Payment may also be made electronically through CCC Online at copyright.com. Other copying for republication, resale, advertising or promotion, or any form of systematic or multiple reproduction of any material in this book is prohibited except with permission in writing from the publisher. The CCC fee code is 0277-786X/08/\$18.00.

Printed in the United States of America.

Publication of record for individual papers is online in the SPIE Digital Library.

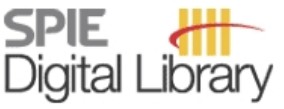

SPIEDigitalLibrary.org

Paper Numbering: Proceedings of SPIE follow an e-First publication model, with papers published first online and then in print and on CD-ROM. Papers are published as they are submitted and meet publication criteria. A unique, consistent, permanent citation identifier (CID) number is assigned to each article at the time of the first publication. Utilization of CIDs allows articles to be fully citable as soon they are published online, and connects the same identifier to all online, print, and electronic versions of the publication. SPIE uses a six-digit CID article numbering system in which:

- The first four digits correspond to the SPIE volume number.

- The last two digits indicate publication order within the volume using a Base 36 numbering system employing both numerals and letters. These two-number sets start with 00, 01, 02, 03, 04 , 05, 06, 07, 08, 09, OA, OB ... 0Z, followed by 10-1Z, 20-2Z, etc.

The CID number appears on each page of the manuscript. The complete citation is used on the first page, and an abbreviated version on subsequent pages. Numbers in the index correspond to the last two digits of the six-digit CID number. 


\section{Contents}

$\checkmark$ Conference Committee

vii Symposium Committees

\section{CLOUDS}

715205 Cloud growth process appeared in the global scale distribution of the cloud optical and microphysical properties retrieved from the satellite remote sensing [7152-04]

T. Y. Nakajima, Tokai Univ. (Japan); K. Suzuki, Colorado State Univ. (United States);

T. Takemura, Kyushu Univ. (Japan); T. Nakajima, Univ. of Tokyo (Japan)

715206 Advances in the remote sensing of clouds and precipitation from CloudSat and the A-Train [7152-05]

G. L. Stephens, Colorado State Univ. (United States); D. G. Vane, Jet Propulsion Lab. (United States)

715207 EarthCARE and its payload [7152-06]

R. V. Gelsthorpe, A. Heliere, A. Lefebvre, J. Lemanczyk, E. Mateu, K. Wallace, European

Space Research and Technology Ctr. (Netherlands)

RAIN

715208 TRMM PR algorithms version 6 status and plans for version 7 [7152-07]

K. Okamoto, Tottori Univ. of Environmental Studies (Japan); R. Meneghini, NASA Goddard Space Flight Ctr. (United States); T. Iguchi, National Institute of Information and Communications Technology (Japan); J. Awaka, Tokai Univ. (Japan); S. Shimizu, JAXA/Earth Observation Research Ctr. (Japan)

715209 Validation of rain/no-rain threshold value of cloud liquid water for microwave precipitation retrieval algorithm using CloudSat precipitation product [7152-08]

S. Kida, S. Shige, T. Manabe, Osaka Prefecture Univ. (Japan); T. S. L'Ecuyer, Colorado State Univ. (United States); G. Liu, Florida State Univ. (United States)

ATMOSPHERE, GAS, AND RADIATION

7152 OD Impact assessment of additional predictors to the retrieval of atmospheric profiles from infrared radiances [7152-12]

D. Jiang, Hunan Research Institute of Meterological Science (China); C. Dong, National Satellite Meteorological Ctr. (China); R. Huo, R. Cai, Hunan Research Institute of Meterological Science (China)

7152 OE Requirements for an Advanced Low Earth Orbit (LEO) Sounder (ALS) for improved regional weather prediction and monitoring of greenhouse gases [7152-14]

T. S. Pagano, M. T. Chahine, Jet Propulsion Lab. (United States); J. Susskind, NASA Goddard Space Flight Ctr. (United States) 
$7152 \mathrm{OH}$ The retrieval of sea fog characteristic from NOAA17 AVHRR3 data [7152-17] Z. Hao, D. Pan, State Oceanic Administration (China); J. Zou, State Oceanic Administration (China) and Shanghai Institute of Technical Physics (China); X. He, State Oceanic Administration (China)

7152 ol Atmospheric correction for land observing sensor AVNIR-2 [7152-19] S. Mukai, I. Sano, K. Ishii, M. Yasumoto, Kinki Univ. (Japan); T. Sugimura, RESTEC (Japan)

$7152 \mathrm{OL} \quad$ Validation of MODIS aerosol optical depth retrievals over the China Sea [7152-22] $X$. Deng, Anhui Institute of Meteorology (China) and State Oceanic Administration (China): D. He, Anhui Climate Ctr. (China); H. Huang, D. Pan, State Oceanic Administration (China)

$71520 \mathrm{M}$ Improvement of $\mathrm{PM}_{2.5}$ analysis by using AOT and lidar data [7152-23] I. Sano, Kinki Univ. (Japan); M. Mukai, JAXA/EORC (Japan); Y. Okada, S. Mukai, Kinki Univ. (Japan); N. Sugimoto, I. Matsui, A. Shimizu, National Institute for Environmental Studies (Japan)

$71520 \mathrm{~N} \quad$ Relation between cloud optical thickness and precipitation derived from space-borne measurements [7152-24]

K. Masuda, T. Kobayashi, Meteorological Research Institute (Japan)

715200 Preliminary comparison of OMI PBL SO2 data to in-situ measurements in Beijing [7152-25]

Z. Cai, Y. Liu, P. Wang, X. Meng, J. Xia, Institute of Atmospheric Physics (China)

7152 OP Detection of dust and sandstorms from Taklamakan Desert to Japan by using MODIS mosaic images [7152-26]

Y. Kato, Fukui Univ. of Technology (Japan)

$71520 Q \quad$ Validation of aerosol-type classification from satellite remote sensing [7152-27]

J. Kim, J. Lee, J. Mok, Yonsei Univ. (South Korea); Y. Kim, National Institute of Meteorological Research (South Korea)

7152 OR Picosecond laser pulse distortion in a turbulent atmosphere [7152-28]

J. Blazej, I. Prochazka, L. Kral, Czech Technical Univ. in Prague (Czech Republic) 


\title{
Conference Committee
}

\author{
Conference Chairs \\ Graeme L. Stephens, Colorado State University (United States) \\ Takashi Y. Nakajima, Tokai University (Japan) \\ Program Committee
}

Donald E. Hinsman, World Meteorological Organization (Switzerland)

Liu Yi, Institute of Atmospheric Physics (China)

Barbara J. Ryan, U.S. Geological Survey (United States)

Byung Ju Sohn, Seoul National University (South Korea)

Guangyu Shi, Institute of Atmospheric Physics (China)

S. N. Tripathi, Indian Institute of Technology Kanpur (India)

Si-Chee Tsay, NASA Goddard Space Flight Center (United States)

Session Chairs

1 Clouds

Graeme L. Stephens, Colorado State University (United States)

2 Rain

Takashi Y. Nakajima, Tokai University (Japan)

3 Aerosols

Takashi Y. Nakajima, Tokai University (Japan)

4 Atmosphere, Gas, and Radiation

Liu Yi, Institute of Atmospheric Physics (China) 
Downloaded From: https://www.spiedigitallibrary.org/conference-proceedings-of-spie on 26 Apr 2023

Terms of Use: https://www.spiedigitallibrary.org/terms-of-use 


\title{
Symposium Committees
}

\author{
Symposium General Chairs
}

Upendra N. Singh, NASA Langley Research Center (United States)

Robert J. Frouin, Scripps Institution of Oceanography, University of California, San Diego (United States)

Frederic Guillard, Government of New Caledonia (New Caledonia)

Symposium General Cochairs

Hiroshi Kumagai, National Institute of Information and Communications Technology (Japan)

A. S. Kiran Kumar, Indian Space Research Organisation (India)

Delu Pan, State Oceanic Administration (China)

Symposium Honorary Chairs

Michael Freilich, NASA Headquarters (United States)

Mary Ellen Kicza, NOAA-National Oceanic and Atmospheric Administration (United States)

Fabrice Colin, Institut de Recherche pour le Développement (New Caledonia)

Yasushi Horikawa, Japan Aerospace Exploration Agency (Japan)

G. Madhavan Nair, Indian Space Research Organisation (India)

Shuguang Wang, Chinese Society of Oceanography (China)

Symposium Honorary Cochairs

Jimmie Rodgers, Secretariat of the Pacific Communities

Lionel Loubersac, Institut Français de Recherche pour L'Exploitation de la Mer (New Caledonia)

Jean-Claude Angue, French Ministry of Research and Technology (New Caledonia)

Symposium Technical Program Chairs

William L. Smith, Hampton University (United States)

Morgan Mangeas, Université de la Nouvelle-Calédonie (New Caledonia)

Kohei Mizutani, National Institute of Information and Communications Technology (Japan)

Vaddadi Jayaraman, Indian Space Research Organisation (India)

Chuqun Chen, South China Sea Institute of Oceanology (China)

Symposium Steering Committee

Chair: Upendra Singh, NASA Langley Research Center (United States)

Cochair: George J. Komar, NASA Goddard Space Flight Center (United States) 
Kazuhiro Asai, Tohoku Institute of Technology (Japan)

Robert Frouin, Scripps Institution of Oceanography, University of California, San Diego (United States)

Frederic Guillard, Government of New Caledonia (New Caledonia)

Toshikazu Itabe, National Institute of Information and Communications Technology (Japan)

Achuthan Jayaraman, Physical Research Laboratory (India)

Jack A. Kaye, NASA Headquarters (United States)

A. S. Kiran Kumar, Indian Space Research Organisation (India) Stephen A. Mango, NOAA National Polar-orbiting Operational Environmental Satellite System (United States)

Takashi Moriyama, Japan Aerospace Exploration Agency (Japan)

Delu Pan, State Oceanic Administration (China)

Stephen P. Sandford, NASA Langley Research Center (United States)

Jinxue Wang, Raytheon Company (United States)

Symposium International Organizing Committee

Yu-Hwan Ahn, Korea Ocean Research and Development Institute (Republic of Korea)

Jinyu Cheng, Chinese Society of Oceanography (China)

Adarsh Deepak, Science and Technology Corporation (United States)

Franco Einaudi, NASA Goddard Space Flight Center (United States)

Wolf Forstreuter, Pacific Islands Applied Geoscience Commission

Ramesh Kakar, NASA Headquarters (United States)

Yves Lafoy, Regional Cooperation Department of New Caledonia (New Caledonia)

Mervyn J. Lynch, Curtin University of Technology (Australia)

Shailesh R. Nayak, Indian Space Research Organisation (India)

Haruhisa Shimoda, Japan Aerospace Exploration Agency (Japan)

Lelia B. Vann, NASA Langley Research Center (United States)

Yoshifumi Yasuoka, The University of Tokyo (Japan)

James R. Yoder, Woods Hole Oceanographic Institution (United States)

Local Organizing Committee

Yann-Eric Boyeau, Government of New Caledonia (New Caledonia)

Damien Buisson, Government of New Caledonia (New Caledonia)

Marc Despinoy, Institut de Recherche pour le Développement (New

Caledonia)

Morgan Mangeas, Université de la Nouvelle-Calédonie (New Caledonia) 